JOTE Volume 2 Nomor 1 Tahun 2020 Halaman 177-187 JOURNAL ON TEACHER EDUCATION

Research \& Learning in Faculty of Education

UNIIERESTAS

\title{
PENERAPAN MODEL PEMBELAJARAN Number Head Together (NHT) UNTUK MENINGKATKAN HASIL BELAJAR IPA SISWA KELAS III SD NEGERI PARUMAAN
}

\author{
Blasius Bura \\ SD Negeri Parumaan, Sikka, NTT \\ Email: burablasius@gmail.com
}

\begin{abstract}
Abstrak
Penelitian ini bertujuan untuk meningkatkan hasil belajar IPA setelah penerapan model pembelajaran NHT pada siswa kelas III SD Negeri Parumaan Tahun Ajaran 2018/2019. Jenis penelitian ini adalah Penelitian Tindakan Kelas dengan subjek seluruh siswa kelas III SD Negeri Parumaan Tahun Ajaran 2018/2019 berjumlah 22 orang. Data hasil belajar yang dikumpulkan dengan tes hasil belajar IPA. Selanjutnya data tersebut dianalisis dengan metode analisis deskriptif kuantitatif. Hasil penelitian menunjukkan bahwa penerapan Model Pembelajaran NHT dapat meningkatkan Hasil belajar pada pembelajaran IPA siswa kelas III di SD Negeri Parumaan. Hal ini dapat diketahui dari hasil yang diperoleh pada siklus I, ratarata hasil belajar siswa pada siklus I hanya mencapai 52,64 dengan persentase sebesar $52,64 \%$ termasuk kategori hasil belajar sedang. Setelah diadakan perbaikkan pada siklus II, diperoleh hasil belajar mencapai 81,93 dengan persentase $81,93 \%$ termasuk kategori tinggi. Dengan demikian dapat disimpulkan bahwa penerapan model pembelajaran NHT pada mata pelajaran IPA dapat meningkat.
\end{abstract}

Kata kunci: Number Head Together, Hasil Belajar

\begin{abstract}
This study aims to improve science learning outcomes after the implementation of the NHT learning model in grade III SD Negeri Parumaan for the 2018/2019 academic year. This type of research is Classroom Action Research with the subject of all students of class III SD Negeri Parumaan for the 2018/2019 academic year totaling 22 people. The learning outcome data were collected by means of a science learning outcome test. Furthermore, the data were analyzed using quantitative descriptive analysis method. The results showed that the application of the NHT Learning Model can improve learning outcomes in science learning for grade III students at SD Negeri Parumaan. This can be seen from the results obtained in the first cycle, the average student learning outcomes in the first cycle only reached 52.64 with a percentage of $52.64 \%$ including the category of moderate learning outcomes. After the improvement was held in the second cycle, the learning outcomes were 81.93 with a percentage of $81.93 \%$ in the high category. Thus it can be concluded that the application of the NHT learning model in science subjects can increase.
\end{abstract}

Keywords: Number Head Together, Learning Outcomes 


\section{PENDAHULUAN}

Proses pembelajaran yang diharapkan terjadi di tiap-tiap sekolah adalah suatu proses yang dapat mengembangkan potensi-potensi siswa secara menyeluruh dan terpadu. Karena itu dalam proses pembelajaran, guru tidak hanya dituntut menyampaikan materi pembelajaran akan tetapi mengaktualisasi peran strategisnya dalam upaya membentuk watak siswa melalui pengembangan kepribadian dan nilai-nilai yang berlaku. Dalam proses pembelajaran akan diajarkan materimateri yang ada pada masing-masing mata pelajaran salah satunya mata pelajaran IPA. Di sekolah dasar IPA dipelajari sejak kelas 1 SD dengan mengenal segala sesuatu yang ada disekitar siswa. IPA sangat perlu diajarkan agar kehidupan manusia semakin maju dengan beragam pengetahuan dan teknologi yang diciptakan. Siswa yang memiliki pengetahuan pada suatu mata pelajaran dapat dilihat dari hasil belajar yang diperoleh. Begitu pula dengan mata pelajaran IPA dapat dilihat dari hasil belajar IPA siswa tersebut. Namun pada pelaksanaan pembelajaran IPA masih banyak siswa yang belum memperoleh hasil belajar IPA yang memuaskan.

Berdasarkan pengalaman mengajar di kelas III SD Negeri Parumaan dalam proses pembelajaran IPA lebih banyak menggunakan metode ceramah yang proses pembelajaran masih berpusat pada guru. Proses pembelajaran guru lebih banyak memberikan informasi, siswa sering bermain, mengobrol dengan teman pada saat guru menjelaskan materi pembelajaran. Konsep materi pelajaran belum dikuasai siswa. Dengan proses pembelajaran yang seperti itu mengakibatkan siswa kurang aktif, cenderung pasif dalam mengikuti proses pembelajaran, siswa kurang fokus dalam memahami materi pembelajaran yang diberikan. Tidak ada aktivitas siswa yang sangat berperan dalam pembelajaran.

Hal ini diperkuat dengan hasil ulangan harian yaitu dengan rata-rata hasil ulangan harian mata pelajaran IPA 60,70 yang belum memenuhi KKM yang ditentukan yaitu 70. Untuk mengatasi permasalahan tersebut, maka perlu dicarikan solusi agar pembelajaran IPA yang dilaksanakan menjadi lebih bermakna sehingga dapat memberikan pengaruh positif terhadap peningkatan hasil belajar IPA siswa SD Negeri Parumaan. Salah satu solusi untuk mengatasi permasalahan tersebut, yaitu dengan menerapkan salah satu model pembelajaran yang mampu memberikan pengalaman belajar yang melibatkan proses mental dan fisik melalui interaksi antara siswa dengan guru, siswa dengan siswa, lingkungan, dan sumber belajar lainnya dalam situasi yang menyenangkan bagi siswa. 
Maka dari itu, tampak bahwa hasil belajar IPA masih sangat rendah. Oleh karena itu, diupayakan jalan keluar untuk mengatasi masalah tersebut dengan menerapkan model pembelajaran Number Head Together (NHT). Kurniasih \& Sani, (2015) menyatakan bahwa pembelajaran kooperatif tipe NHT ini lebih menekankan pada struktur khusus yang dirancang untuk mempengaruhi pola interaksi siswa agar memiliki tujuan untuk meningkatkan penguasaan akademik. Model pembelajaran Number Head Together (NHT) memiliki beberapa keunggulan yaitu: 1) model ini menuntut siswa harus aktif semua, 2) dengan model pembelajaran ini juga, siswa dituntut untuk melakukan diskusi dengan sungguh-sungguh, 3) siswa yang pandai dapat mengajari siswa yang kurang pandai.

Berdasarkan uraian yang telah dipaparkan di atas, maka dalam penelitian ini akan dilakukan Penerapan Model Pembelajaran Number Head Together (NHT) Untuk Meningkatkan Hasil Belajar IPA Siswa Kelas III SD Negeri Parumaan Tahun Ajaran 2018/2019. Berdasarkan latar belakang diatas, maka dapat dirumuskan masalahnya sebagai berikut, "Apakah dengan menerapan model pembelajaran Number Head Together (NHT) dapat meningkatkan hasil belajar IPA Siswa Kelas III SD Negeri Parumaan Tahun Ajaran 2018/2019? Berdasarkan rumusan masalah penelitian ini, maka tujuan penelitian ini adalah "untuk mengetahui peningkatkan hasil belajar IPA Siswa Kelas III SD Negeri Parumaan Tahun Ajaran 2018/2019. dengan penerapan model pembelajaran Number Head Together (NHT)".

Wahaya (dalam Trianto, 2010) mengatakan bahwa, "IPA adalah suatu kumpulan pengetahuan tersusun secara sistematik dan dalam penggunaannya secara umum terbatas pada gejalagejala alam. Perkembangannya tidak hanya ditandai oleh adanya kumpulan fakta, tetapi oleh adanya metode ilmiah dan sikap ilmiah". Trianto, (2011) menyimpulkan bahwa IPA adalah suatu kumpulan teori yang sistematis, penerapannya secara umum terbatas pada gejala-gejala alam, lahir dan berkembang melalui metode ilmiah seperti observasi dan eksperimen serta menuntut sikap ilmiah seperti rasa ingin tahu, terbuka, jujur dan sebagainya. Dari secara kelompok yang berpusat pada siswa. Melalui kegiatan kelompok semua siswa terlibat dalam mempelajari dan menyelesaikan tugas yang dibebankan. Model pembelajaran kooperatif merupakan teknik-teknik kelas praktis yang dapat digunakan guru setiap hari untuk membantu siswa belajar setiap mata pelajaran, mulai dari keterampilan dasar sampai memecahkan masalah yang kompleks (Nur, 2005; Suprijono, 2009; Agustin, dkk, 2013). Maka 
dengan pembelajaran kooperatif siswa diharapkan mampu menciptakan situasi dimana Maka dari itu untuk mendukung pemecahan masalah digunakan model pembelajaran kooperatif tipe NHT. Menurut Trianto (2007) Model pembelajaran NHT merupakan suatu pendekatan untuk melibatkan banyak siswa dalam memperoleh materi yang tercakup dalam suatu pelajaran dan mengecek pemahaman mereka terhadap isi pelajaran.

NHT merupakan salah satu jenis model pembelajaran kooperatif yang dikembangkan oleh Spencer Kagan (1992) untuk melibatkan lebih banyak siswa dalam menelaah materi yang tercakup dalam suatu pelajaran dan mengecek pemahaman mereka terhadap isi pelajaran (Trianto, 2007; Kusumaningtyas, dkk, 2014; Miaz, 2015; Puspa, dkk, 2015, Kurniasih \& Sani, 2015). NHT adalah suatu metode belajar yang setiap anak diberi nomor kemudian dibuat satu kelompok lalu guru memanggil secara acak nomor dari siswa tersebut. Shoimin, (2014) menyatakan bahwa model pembelajaran NHT adalah suatu model pembelajaran berkelompok yang setiap anggota kelompoknya bertanggung jawab atas tugas kelompoknya, sehingga tidak ada pemisahan antar siswa yang satu dengan yang lainnya. Model pembelajaran ini harus dilaksanakan dengan memberikan penomoran sehingga setiap siswa dalam timnya mempunyai nomor yang berbeda-beda, sesuai dengan jumlah siswa di dalam kelompok (Kurniasih \& Sani, 2015).

Dari beberapa uraian di atas dapat disimpulkan bahwa NHT adalah model pembelajaran yang dapat memberikan rasa tanggung jawab kepada anak untuk menyelesaikan tugas dan melatih perkembangan otak anak untuk mencari tahu sendiri apa yang telah ditugaskan. Langkah-langkah tersebut kemudian dikembangkan oleh Kurniasih \& Sani, (2015) menjadi enam langkah sebagai berikut. Langkah 1. Persiapan Dalam tahapan ini guru mempersiapkan rancangan pelajaran yang sesuai dengan model pembelajaran kooperatif tipe NHT. Langkah 2. Membagi kelompok Kelompok yang dibentuk, harus sesuai dengan model pembelajaran kooperatif tipe NHT, yakni beberapa kelompok yang beranggotakan 3-5 orang siswa. Kemudian menomori serta memberi nama setiap kelompok. Usahakan masing-masing kelompok terdiri dari beragam karakter anak. Langkah 3. Tiap kelompok harus memiliki buku panduan Lengkapi setiap kelompok dengan buku panduan agar memudahkan mereka dalam mengerjakan tugas yang diberikan. Langkah 4. Memulai diskusi Memulailah memberikan tugas kepada siswa. Dan dalam kerja kelompok tersebut, pastikan semua siswa mengerti dengan pertanyaan serta jawaban yang hendak diberikan. 
Langkah 5. Memanggil nomor anggota Dalam tahap ini, guru menyebut satu nomor dan para siswa dari tiap kelompok dengan nomor yang sama mengangkat tangan dan menyiapkan jawaban kepada siswa dikelas. Langkah 6. Mengakhiri dengan kesimpulan Guru bersama siswa menyimpulkan jawaban akhir dari semua pertanyaan yang telah dibahas.

Ibrahim, (2000) mengemukakan tiga tujuan yang hendak dicapai dalam pembelajaran kooperatif dengan tipe NHT yaitu: 1) Hasil belajar akademik struktural Bertujuan untuk meningkatkan kinerja siswa dalam tugas-tugas akademik. 2) Pengakuan adanya keragaman Bertujuan agar siswa dapat menerima teman-temannya yang mempunyai berbagai latar belakang. 3) Pengembangan ketrampilan sosial Bertujuan untuk mengembangkan ketrampilan sosial siswa. Menggunakan model pembelajaran kooperatif model Number Head Together (NHT) memiliki beberapa kelebihan, seperti yang diungkapkan oleh Kurniasih \& Sani, (2015) bahwa "model pembelajaran Number Head Together (NHT) memiliki beberapa kelebihan yaitu: 1) model ini menuntut siswa harus aktif semua, 2) dengan model pembelajaran ini juga, siswa dituntut untuk melakukan diskusi dengan sungguh-sungguh, 3) siswa yang pandai dapat mengajari siswa yang kurang pandai".

Dalam proses pelaksanaan pembelajaran Number Head Together (NHT) akan membantu untuk menyampaikan materi pembelajaran IPA sehingga siswa akan fokus pada proses pembelajaran dan dapat memahami materi yang diberikan, hal ini diharapkan akan dapat membantu siswa untuk memperoleh hasil belajar yang memuaskan. Maka dapat disimpulkan melalui penerapan model pembelajaran Number Head Together (NHT) diharapkan hasil belajar siswa meningkat. Berdasarkan landasan teori dan kerangka berpikir di atas, dapat dirumuskan hipotesis tindakan sebagai berikut. "Jika model pembelajaran Number Head Together (NHT) diterapkan secara optimal, maka hasil belajar IPA pada Siswa Kelas III SD Negeri Parumaan Tahun Ajaran 2018/2019 dapat ditingkatkan"

\section{METODE}

Jenis penelitian yang akan dilaksanakan dalah penelitian tindakan kelas (Classroom Action Research). Penelitian tindakan kelas ini memilki empat tahapan pada satu siklus penelitian. Keempat tahapan tersebut terdiri dari: perencanaan, tindakan, pengamatan, dan refleksi (Arikunto, 2009). Penelitian 
tindakan kelas ini dilaksanakan di SD Negeri Parumaan di Kabupaten Sikka Tahun Ajaran 2018/2019.

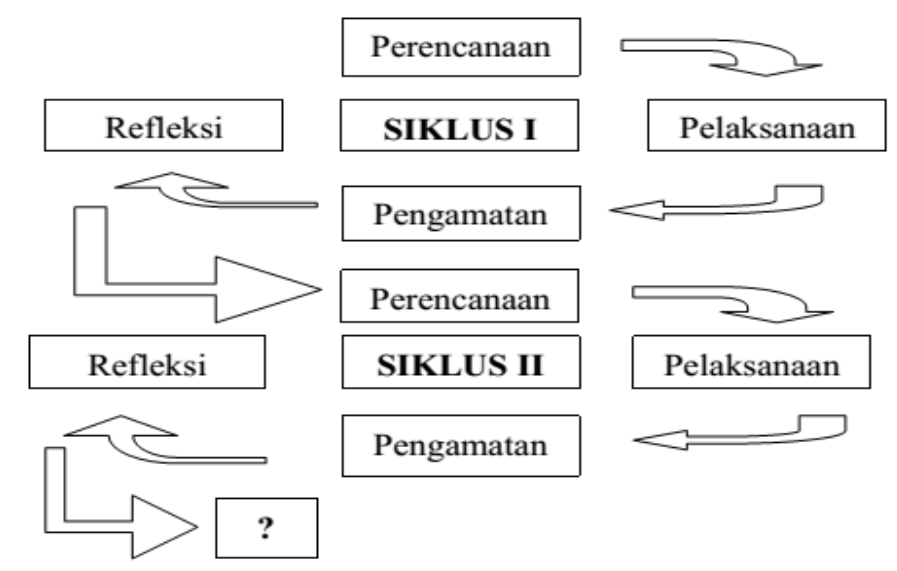

Gambar 1. Langkah-langkah Penelitian Tindakan Kelas

Penelitian tindakan kelas ini dilaksanakan di SD Negeri Parumaan, Kabupaten Sikka dengan subjek penelitian adalah siswa kelas III Tahun Pelajaran 2018/2019, dengan jumlah siswa dan siswi 22 orang.

\section{PEMBAHASAN}

Penelitian tindakan kelas ini dilaksanakan di kelas III SD Negeri Parumaan Tahun Ajaran 2018/2019 dengan jumlah siswa 22 orang. Pelaksanaan penelitian ini dilaksanakan dalam dua siklus. Pada setiap siklus, dilaksanakan dengan 4 kali pertemuan, 3 kali pertemuan untuk pelaksanaan kegiatan pembelajaran dan 1 kali pertemuan untuk pelaksanaan evaluasi hasil belajar IPA. Data yang dikumpulkan pada penelitian ini adalah data hasil belajar IPA siswa kelas III SD Negeri Parumaan setelah diterapkannya model pembelajaran kooperatif tipe Number Head Together (NHT). Data mengenai hasil belajar IPA siswa yang telah dikumpulkan kemudian dianalisis untuk mengetahui peningkatan rata-rata kelas hasil belajar IPA. Pelaksanaan siklus I pada penelitian ini dilaksanakan dalam 4 kali pertemuan, 3 kali pertemuan untuk pelaksanaan kegiatan pembelajaran dan 1 kali pertemuan untuk pelaksanaan evaluasi hasil belajar IPA.

Pertemuan pertama hari Selasa tanggal 25 Oktober 2018, pertemuan kedua hari Jumat tanggal 28 Oktober 2018, pertemuan ketiga dilaksanakan pada hari Selasa tanggal 01 November 2018 dan untuk evaluasi hasil belajar IPA dilaksanakan pada hari Jumat tanggal 04 November 2018 dengan menggunakan instrumen tes. Berdasarkan hasil analisis data pada siklus I diperoleh rata-rata kelas hasil belajar IPA siswa kelas III SD Negeri Parumaan adalah 52,64 dengan 
persentase 52,64\%. termasuk kategori hasil belajar sedang (65-79). Dari data di atas menunjukkan hasil belajar IPA siswa belum mencapai kategori yang diharapkan. Oleh karena itu, dilaksanakan perbaikan pada siklus selanjutnya. Maka tindakan penelitian ini dilanjutkan ke siklus II.

Setelah melaksanakan pembelajaran IPA dengan penerapan model pembelajaran kooperatif tipe Number Head Together (NHT) diperoleh beberapa catatan sebagai hasil observasi dalam pelaksanaan pembelajaran. Setelah dilakukan refleksi ternyata masih terdapat kendala-kendala yang harus diperbaiki pada siklus selanjutnya. Belum tercapainya kategori yang diharapkan disebabkan aktivitas siswa dalam bertanya ataupun menjawab pertanyaan masih kurang. Hanya beberapa siswa yang memiliki keberanian untuk bertanya atau menjawab. Siswa yang pintar sering kali mendominasi pada saat belajar dalam kelompok. Siswa belum bisa berbagai tugas, saling bertukar pendapat, dan bersama-sama mencari informasi untuk menyelesaikan tugas sehingga tugas tidak terselesaikan tepat waktu dan kelompok terkesan pasif. Guru telah berupaya memotivasi siswa agar siswa aktif mengemukakan pendapat, berdiskusi. Berdasarkan refleksi siklus I selanjutnya pada siklus II dilakukan perbaikan atau penyempurnaan. Beberapa upaya yang dilakukan seperti merubah anggota kelompok belajar berdasarkan hasil tes siklus I.

Hal ini dilakukan agar dalam satu kelompok terdiri dari siswa yang memiliki kemampuan merata. Membimbing siswa melatih keterampilanketerampilan kooperatif saat melakukan diskusi dalam kelompok seperti saling berbagi tugas dan saling membantu antara anggota kelompok untuk memahami materi sehingga terjadi interaksi yang positif dan tidak ada yang diam atau pasif. Memberikan pujian dan penguatan juga dilakukan untuk menumbuhkan keberanian dan rasa percaya diri siswa untuk bertanya ataupun menjawab yang berkaitan dengan pembelajaran. Penguatan mempunyai peranan yang sangat penting dalam meningkatkan keefektifan kegiatan pembelajaran.

Pelaksanaan siklus II pada penelitian ini dilaksanakan dalam 4 kali pertemuan, 3 kali pertemuan untuk pelaksanaan kegiatan pembelajaran dan 1 kali pertemuan untuk pelaksanaan evaluasi hasil belajar matematika. Pertemuan pertama hari Selasa tanggal 08 November 2018, pertemuan kedua dilaksanakan hari Jumat tanggal 11 November 2018, pertemuan ketiga dilaksanakan pada hari Selasa tanggal 15 Nopember 2018 dan untuk evaluasi hasil belajar IPA dilaksanakan pada hari Jumat tanggal 18 Nopember 2018 dengan menggunakan instrumen tes. Berdasarkan hasil analisis data pada siklus II diperoleh rata-rata 
hasil belajar IPA siswa kelas III SD Negeri Parumaan mencapai 81,93 dengan persentase $81,93 \%$. ternyata persentase rata-rata hasil belajar IPA sebesar $81,93 \%$ termasuk kategori hasil belajar tinggi (80-89).

Dilihat dari tindakan siklus II menunjukkan telah terjadi peningkatan hasil belajar IPA siswa sesuai dengan indikator keberhasilan yaitu terjadinya peningkatan rata-rata hasil belajar IPA siswa secara klasikal dari siklus I ke siklus II sebesar 9,19 dan perolehan persentase hasil belajar IPA siswa pada siklus II mencapai 81,93 \% berada pada kategori tinggi. Maka dari itu, penelitian ini sudah dikatakan berhasil sehingga siklus II dapat dihentikan. Untuk memudahkan dalam mengetahui peningkatan data tentang hasil belajar siswa terhadap mata pelajaran IPA pada siklus I dan siklus II, maka dibuatlah ringkasan hasil penelitian sebagai berikut.

Tabel 1. Hasil Belajar Siklus I dan II SD Negeri Parumaan

\begin{tabular}{cccc}
\hline Tahapan Siklus & $\begin{array}{c}\text { Rata-rata Hasil } \\
\text { Belajar }\end{array}$ & $\begin{array}{c}\text { Persentase Hasil } \\
\text { Belajar }\end{array}$ & Kategori \\
\hline Siklus I & 52,64 & $52,64 \%$ & Sedang \\
\hline Siklus II & 81,93 & $81,93 \%$ & Tinggi \\
\hline
\end{tabular}

Berdasarkan penelitian yang telah dilaksanakan dalam dua siklus yang setiap siklus terdiri dari empat kali pertemuan yakni tiga kali pertemuan tatap muka dan satu kali pengadaan tes hasil belajar terjadi peningkatan hasil belajar siswa kelas III SD Negeri Parumaan pada pelajaran IPA. Berdasarkan hasil yang diperoleh pada siklus I, rata-rata hasil belajar siswa pada siklus I hanya mencapai 52,64 dengan persentase sebesar 72,74\% termasuk kategori hasil belajar sedang. Belum tercapainya kategori yang diharapkan disebabkan aktivitas siswa dalam bertanya ataupun menjawab pertanyaan masih kurang. Hanya beberapa siswa yang memiliki keberanian untuk bertanya atau menjawab. Siswa yang pintar sering kali mendominasi pada saat belajar dalam kelompok. Siswa belum bisa berbagai tugas, saling bertukar pendapat, dan bersama-sama mencari informasi untuk menyelesaikan tugas sehingga tugas tidak terselesaikan tepat waktu dan kelompok terkesan pasif.

Guru telah berupaya memotivasi siswa agar siswa aktif mengemukakan pendapat, berdiskusi. Yamin (2007) menyatakan "keaktifan siswa dalam proses pembelajaran dapat merangsang dan mengembangkan bakat yang dimilikinya, berpikir kritis dan dapat memecahkan masalah dalam kehidupan sehari- hari". 
Dalam hal ini keaktifan siswa dalam proses pembelajaran adalah suatu kegiatan yang dilakukan siswa yang terlibat secara aktif dalam mengemukakan ide, bertanya, menyampaikan pendapat selama proses pembelajaran dalam menemukan suatu konsep. Kendala kendala yang dialami pada siklus I menjadi hambatan bagi siswa dalam mengikuti proses pembelajaran di kelas, sehingga pada siklus I belum mencapai target yang ditetapkan. Berdasarkan refleksi siklus I selanjutnya pada siklus II dilakukan perbaikan atau penyempurnaan.

Beberapa upaya yang dilakukan seperti merubah anggota kelompok belajar berdasarkan hasil tes siklus I. Hal ini dilakukan agar dalam satu kelompok terdiri dari siswa yang memiliki kemampuan merata. Membimbing siswa melatih keterampilan-keterampilan kooperatif saat melakukan diskusi dalam kelompok seperti saling berbagi tugas dan saling membantu antara anggota kelompok untuk memahami materi sehingga terjadi interaksi yang positif dan tidak ada yang diam atau pasif. Berdasarkan hasil analisis data pada siklus II maka diperoleh rata-rata hasil belajar siswa mencapai 81,93 dan persentase nilai ratarata siswa sudah mencapai $81,93 \%$ berada dalam kategori tinggi dengan tingkat rentang ketuntasan berada pada rentang skor 80- 89. Dari analisis data pada siklus I dan siklus II di atas, diketahui bahwa hasil belajar IPA meningkat melalui model pembelajaran kooperatif tipe Number Head Together (NHT) pada siswa kelas III SD Negeri Parumaan semester ganjil tahun pelajaran 2018/2019. Hal ini dapat dilihat dari ratarata hasil belajar siswa secara klasikal pada siklus I sebesar 52, 64 dengan persentase rata-rata 52,64\% yang tergolong pada kategori sedang. Pada siklus II rata-rata meningkat menjadi 81,93 dengan persentase rata-rata sebesar $81,93 \%$ yang berada dalam kategori tinggi.

Seiring dengan peningkatan rata-rata hasil belajar siswa persentase ratarata pun ikut meningkat. Peningkatan persentase rata-rata dari siklus I ke siklus II sebesar 9,19\%. Terjadinya peningkatan hasil belajar siswa kelas III semester ganjil pada mata pelajaran IPA disebabkan oleh pada pelaksanaan tindakan siklus II tidak lagi muncul kendala-kendala pada siklus I. Beberapa upaya yang dilakukan pada siklus II seperti merubah anggota kelompok belajar berdasarkan hasil tes siklus I. Hal ini dilakukan agar dalam satu kelompok terdiri dari siswa yang memiliki kemampuan merata. Membimbing siswa melatih keterampilanketerampilan kooperatif saat melakukan diskusi dalam kelompok seperti saling berbagi tugas dan saling membantu antara anggota kelompok untuk memahami materi sehingga terjadi interaksi yang positif dan tidak ada yang diam atau pasif. Memberikan pujian dan penguatan juga dilakukan untuk menumbuhkan 
keberanian dan rasa percaya diri siswa untuk bertanya ataupun menjawab yang berkaitan dengan pembelajaran.

Melihat peningkatan hasil belajar siswa dalam pembelajaran IPA yang menerapkan metode pembelajaran pemberian tugas, dapat diketahui bahwa metode pemberian tugas ini sangat memberikan sumbangan positif dalam proses pembelajaran dan hasil belajar siswa yang optimal serta sangat baik digunakan dalam peningkatan kualitas pembelajaran sekolah dasar. Pembelajaran pemberian tugas dapat memudahkan siswa melakukan penyesuaian sosial, mengembangkan kegembiraan belajar yang sejati, memungkinkan siswa saling belajar mengenai sikap, keterampilan, informasi, perilaku, sosial dan pandangan. Dari uraian di atas, secara umum telah mampu menjawab rumusan masalah. Penelitian ini dapat dikatakan berhasil, karena semua kriteria yang ditetapkan telah terpenuhi. Jadi, dapat dinyatakan bahwa penerapan model pembelajaran Kooperatif tipe Numbered Head Together (NHT) dapat meningkatkan hasil belajar IPA siswa kelas III SD Negeri Parumaan Tahun Ajaran 2018/2019.

\section{KESIMPULAN}

Dari hasil dan pembahasan penelitian maka dapat disimpulkan sebagai berikut. Terjadinya peningkatan hasil belajar siswa dalam mata pelajaran IPA melalui penerapan model pembelajaran (Number Head Together) NHT pada siswa kelas III SD Negeri Parumaan. Hal ini terbukti dari peningkatan rata-rata hasil belajar, persentase rata-rata hasil belajar, pada siklus I diperoleh nilai rata-rata hasil belajar 52,64, persentase hasil belajar $52,64 \%$ berada pada kategori "sedang". Sedangkan pada siklus II hasil belajar meningkat yaitu nilai rata-rata hasil belajar siswa mencapai 81,93 persentase rata-rata $81,93 \%$ berada dalam kategori "tinggi".

\section{DAFTAR PUSTAKA}

Dimyati dan Moedjiono. 2009. Belajar dan Pembelajaran. Jakarta: Rineka Cipta

Ibrahim, M. 2000. Pembelajaran Kooperatif. University Press. Surabaya.

Kurniasih \& Sani. 2015. Model Pembelajaran. Jakarta : Kata Pena

Kusumaningtyas, Y. P., \& Kusmayadi, T. A. (2014). Eksperimentasi Model Pembelajaran Think Talk Write ( Ttw ) Dan Numbered Head Together ( Nht ) Terhadap Prestasi Belajar Matematika Ditinjau Dari Konsep Diri Belajar Matematika Siswa Di Smp Negeri E-Kabupaten Blora. Jurnal Elektronik Pembelajaran Matematika 2(2), 215-225. 
Lapono, Nabisi, dkk. 2008. Belajar dan Pembelajaran SD. Jakarta: Direktorat Jenderal Pendidikan Tinggi Departemen Pendidikan Nasional.

Miaz, Y. (2015). The Implementation Of Numbered Heads Together To Improve The Students' Achievement Of Social Sciences In Primary School. Research Journal of Social Sciences. 8 (10). 40-45.

Nur, Mohamad. 2005. Pembelajaran Kooperatif. Jawa Timur: Depdiknas.

Nurkancana dan Sunartana. 1990. Evaluasi Hasil Belajar. Surabaya : Usaha Nasional.

Purwanto, M. Ngalim. 2000. Psikologi Pendidikan. Bandung : Remaja Rosdakarya.

Puspa, D., Danti, N., Suprayitno, I. J., Prihaswati, M., Konstruktivisme, P., \& Belajar, P. (2015). Perbandingan Pembelajaran Number Head Together Dengan Team Assisted Individualization Berpendekatan, 2(April). JKPM. 2 (1). 15-21. 